\title{
The Legal Consequences of a Notary Being Declared Bankrupt by A Court Decision (Case Study of Decision Number 20/Pdt.Sus-Pkpu/2020/Pn Niaga Sby)
}

\author{
Zulfikar Judge \\ \{Zulfikar.judge@esaunggul.ac.id\} \\ Universitas Esa Unggul Jakarta, Indonesia
}

\begin{abstract}
In Law Number 2 of Universitas Borobudur 2014 concerning Notary Positions, there is no prohibition for notaries to do business outside their positions. This case study aims to analyze a notary's business bankruptcy and how the legal consequences for a notary being declared bankrupt based on a court decision on the basis of Article 12 (a). The method used is normative juridical. The results of the analysis show that the legal consequences of notaries being declared bankrupt will lose all rights under their authorities and have no obligation to carry out services for making authentic deeds, agreements and other legal actions. The lawful situation of a legal official who is bankrupt dependent on a court choice on account of Decision Number 20/Pdt.Sus-PKPU/2020/PN Niaga Sby, when alluding to the arrangements of Law Number 37 of 2004 concerning Bankruptcy and Postponement of Obligation to Pay Debt, and status and position as a borrower.
\end{abstract}

Keywords: Bankruptcy; Dismissal; Disrespectful; Notary

\section{Introduction}

Notary is one of the legal professions that carries out some of the activities of state administration to provide services to the general public in the civil sector [1]. The notary's authority is obtained directly by the state by attribution which is delegated based on statutory provisions [2], therefore the notary is authorized to make important documents in the form of authentic deeds and other authorities related to legal actions, agreements or stipulations desired by the parties. stated in an authentic deed [3].

In order for this authority to be carried out in accordance with its portion, the government issues legal regulations that regulate all notary activities, ranging from authority, obligations to prohibitions that are not allowed to be violated because there are sanctions from such actions. The regulation is contained in Law No. 2 of 2014 as a substitute for Law No. 30 of 2004 concerning Notary Positions (UUJN) whose existence is made to define and determine all obligations given by the government to this notary so that the purpose of forming an independent notary and serving society can be realized as expected [4].

Someone who wants to become a public official or work as a notary is necessary to have special skills in the field of law. According to Habib Adjie, it is called an esoteric position, which means that it must be studied specifically in this case, it must go through stages of special 
education and have adequate skills and abilities to carry out various tasks in the notary field [5] Therefore, in carrying out the duties of his position, a notary must also be careful, thorough and impartial and have the skills to master specifically in the field of notary science and master science in the field of law in general [6].

In providing services to the community, sometimes notaries fall or are vulnerable to dealing with legal problems, one of which is being declared bankrupt by a court decision whose sentence can be dishonorably dismissed as regulated in Article 12 letter a of the UUJN. However, the issue of notary bankruptcy regulated in the $U U J N$ does not explain or there are no provisions in detail and clearly regulate because of what factors the notary is declared bankrupt whether because he does not carry out his duties and authorities in a real time or there are other things.

This is unique in relation to the arrangements in Article 1 number 11 of Law Number 37 of 2004 concerning Bankruptcy and Postponement of Debt Payment Obligations (hereinafter alluded to as the KPKPU Law) which unmistakably expresses that the subject of liquidation is an individual and a legitimate substance, and there are special cases for insolvency resources which are controlled In Article 22 of the KPKPU Law, generally, cash got from the compensation of a position isn't an object of chapter 11 resources. Whenever announced bankrupt, it just loses the option to control resources and doesn't kill the right as a legal official in his/her position.

If we look at the explanation of the two provisions of the law, where if a notary is declared bankrupt by a court decision, then the provisions must also refer to the PKPU Law which is lex specialist as an inseparable legal norm. However, between the $U U J N$ and the PKPU Law, when a notary is declared bankrupt, there is a conflict of norms that have different legal implications, where Article 12 letter a of the $U U J N$ notary who is declared bankrupt by a court decision is dishonorably dismissed, while Article 22 of the KPKPU Law does not eliminate or dismiss as a notary and only lose the right to control the assets.

In fact, it was found that the notary also has another profession as a businessman where to carry out his business development activities he has taken legal action on his personal behalf, namely making capital loan agreements to third parties, both banks and individuals. However, in the course of his business, he did not progress, even on the contrary, he went bankrupt which resulted in his debts being unable to be paid on time, so the last resort he did was to apply for a Suspension of Debt Payment Obligation (PKPU) at the Commercial Court.

This is like what happened to Notary Devi Chrisnawati in the case of Decision 20/Pdt.SusPKPU/2020/PN Niaga Sby, where Notary Devi Chrisnawati submitted a request for a postponement of debt payment $(P K P U)$ at the Surabaya Commercial Court which was filed for herself because the person concerned is entangled in debts that are due and collectible, but are unable to pay the debts of more than one creditor. The PKPU application submitted was granted, so Devi Chrisnawati was declared bankrupt with all the legal consequences. In the interim, the individual concerned is additionally joined to the situation of a legal official, so that dependent on the arrangements of Article 12 letter a UUJN specifies that a public accountant can be disgracefully excused from his situation by the Minister at the idea of the Central Supervisory Council (MPW) whenever pronounced bankrupt dependent on a court choice that has extremely durable legitimate power.

With this occurrence, the East Java Ministry of Law and Human Rights Regional Office and the East Java Regional Supervisory Council (MPW) have announced Notary Devi Chrisnawati to be excused based on Article 12 letter an of the UUJN which expresses that the legal official has been shamefully excused from her situation by the Minister at the idea of the Central Supervisory Council (MPP) whenever pronounced bankrupt dependent on a court choice that has extremely durable lawful power [7] 
Taking into account the legal issues above, the authors are interested in compiling a scientific paper in the form of a thesis with the title: "The Legal Consequences of Notary Being Declared Bankrupt by Court Decision (Case Study Decision Number 20/Pdt.Sus-PKPU/2020/PN Niaga $S b y)$. Based on the title of the study, the research problems arise, namely:

1. What are the legal consequences for a notary being declared bankrupt based on Court Decision Number 20/Pdt.Sus-PKPU/2020/PN Niaga Sby?

2. What is the legal position of a notary who is bankrupt based on a court decision Number 20/Pdt.Sus-PKPU/2020/PN Niaga Sby?

\section{General review}

\subsection{Legal Certainty Theory}

According to Michael Jefferson, there are (4) four conditions to realize the consequences that exist in the principles and methods of legality to achieve legal certainty, namely:

a. There is no ambiguity in the law (laws must not be vague);

b. The legislature is prohibited from making laws that are retroactive in nature (the legislature must not create offenses to cover wrongdoing retrospectively);

c. The judiciary must not create new offenses and perhaps;

d. The law must be interpreted in a limited or strict manner (criminal statutes should be strictly construed).[8]

Based on the four conditions for achieving legal certainty, in general there are 2 (two) main elements that can lead to the achievement of legal certainty, namely:

a. There is a law. The law and must not be multi-interpreted because it can result in legal uncertainty in its application in court.

b. The power itself that ratifies the law applies. That power is not allowed to arbitrarily apply the principle of legality, then it is followed by a power structure based on the trias politica so as to guarantee legal certainty.[9]

Legal certainty will be achieved through positivist legal regulations, but at the level of practice in court there must also be a consistent attitude from judges as implementers of the rules that have been made so as to create legal certainty.

\subsection{Theory of Justice}

John Rawls argues that the procedure towards a fair result must be carried out because there are no independent criteria that are used as a reference so that real results can be fair. In addition, John Rawls also reiterated that it cannot be said that certain conditions are fair because justice can be achieved by following fair procedures." This will allow too much and lead to unfair consequences ".[10]

\subsection{Definition of Bankruptcy}

\section{a) Economics}

In economics, bankruptcy is a condition where a person and/or legal entity based on a court decision is declared bankrupt. A person and/or legal entity can be declared bankrupt if they are no longer able to pay their debts to creditors even though their assets are used to pay their debts. 


\section{b) Legal studies}

As indicated by Article 1 point 1 of the KPKPU Law, the meaning of liquidation is general seizure of all resources of the Bankrupt Debtor whose administration and repayment is completed by the Curator under the management of the Supervisory Judge as controlled in this Law.

\subsection{Conditions for Filing Bankruptcy}

As indicated by Article 2 Paragraph (1) of Law Number 37 of 2004 concerning Bankruptcy and Suspension of Debt Payment Obligations, an individual or potentially legitimate substance can be pronounced bankrupt if "a debt holder who has at least two loan bosses and doesn't pay off somewhere around one obligation that has developed and can be gathered, proclaimed bankrupt by a court choice, either at his own solicitation or in line with at least one lender." The accommodation of an application for liquidation against an indebted person must be presented by the approved gatherings as specified in Article 2 Paragraph (2) to Article 2 Paragraph (5) of Law No. 37 of 2004.

\subsection{Legal Subject}

Parties that can be filed for insolvency as per Law Number 37 of 2004 are:

1. Company Person

2. Legal Entity

3. Limited company

4. Civil Guild

5. Firm

6. Cooperative

7. Foundation

\section{Special Overview}

\subsection{Authorities, Obligations, Prohibitions and Sanctions for Notaries}

The power of a public accountant is explicitly controlled in Article 15 of the UUJN identifying with the creation of valid deeds and different specialists that have been specified by law. While the commitments of a public accountant are controlled in Article 16 of the UUJN which underscores the mentality in doing their work, they should act in a reliable, genuine, exhaustive, free, fair-minded, and keep up with the interests of the gatherings engaged with legitimate activities and different commitments identified with the assistance of making deeds and organization of deed stockpiling that has been made.

Meanwhile, the prohibitions and sanctions are closely related to the duties of the notary's authority. This is because the prohibition for a notary is a rule that instructs a notary not to do something that is contrary to the applicable laws and regulations. If the prohibition is violated, the notary may be subject to sanctions.

The prohibition of a notary is regulated in Article 17 of the $U U J N$ which contains at least 9 (nine) points of prohibition, namely not being allowed to carry out tasks outside the area of 
his/her duty area or leaving his/her working area for 7 (seven) consecutive days without a justified reason. Concurrent positions as $A S N /$ civil servant, state officials, advocates, $B U M N / B U M D / \mathrm{S}$ employees are also prohibited and concurrently PPAT/Class II Auction Officers outside the notary's domicile or as a substitute notary is a prohibition that must be avoided. If these prohibitions are violated, the notary may be subject to sanctions in the form of 4 (four) types of sanctions, namely: 1) written warning, 2) temporary dismissal, 3) honorable discharge, and 4) dishonorable discharge.

\subsection{Bankruptcy, PKPU and Disrespectful Dismissal Sanctions for Notaries Declared Bankrupt in $U \boldsymbol{U} \boldsymbol{J N}$}

When discussing bankruptcy at the position of a notary as regulated in Article 9 Paragraph (1) letter a and Article 12 letter a, it must also discuss the KPKPU Law as a special provision or lex specialist which regulates bankruptcy and $P K P U$. The two regulations are correlated, but the impact of these provisions is not the same or has opposite differences.

Article 1 point 1 of the KPKPU Law expresses that "chapter 11 is an overall seizure of all resources of a bankrupt indebted person whose administration and repayment is done by a custodian under the oversight of an administrative appointed authority". Meanwhile Application for Postponement of Debt Payment $(P K P U)$ is an economic juridical facility provided for debtors to resolve financial difficulties so that the debtor concerned has the opportunity to submit a reconciliation plan. This settlement may include an offer to make payments either in whole or in part. PKPU cannot be ended with peace, it will result in the debtor being declared bankrupt. [11]

Parties that can be bankrupt based on the "KPKPU Law are: a) private persons or entities (Article 1 in conjunction with Article 2 paragraph (1); b) debtors who are married (Article 3 in conjunction with Article 4); c) legal entities such as limited liability companies, state companies, cooperatives, associations with the status of legal entities such as foundations (Article 113); d) legacy or inheritance (Article 97 in conjunction with the ninth part of Article 207-211). Meanwhile, the condition for being declared bankrupt is the existence of a debtor's debt that has not been paid to one or two creditors that have matured and can be collected as stipulated in Article 1 Paragraph (2) of the KPKPU Law.

If a legal entity or individual is declared bankrupt by a court decision, it will lose its right or authority to control or manage its assets which are included in the bankruptcy in accordance with the provisions of Article 24 Paragraph (1) of the KPKPU Law. Considering that bankruptcy applies to individuals, which means that it applies to anyone, including people who have certain professions, they can be declared bankrupt if they have fulfilled the conditions stipulated in the $K P K P U$ Law.

Notary is one of the noble professions which is specifically regulated in UUJN, where the obligations, authorities and prohibitions have been arranged in such a way as to be carried out in helping the government provide services to people who need assistance in "making authentic deeds, agreements and other actions. Likewise, the prohibitions that must be avoided because the legal consequences of violating the prohibitions that have been determined can be subject to sanctions from the lightest, to dishonorable dismissal."

Regarding bankruptcy in the position of a notary, the UUJN only regulates bankruptcy as a result of the actions of a notary so that a temporary suspension of punishment is given as long as the notary is undergoing the bankruptcy process in accordance with the provisions of Article 9 Paragraph (1) letter a of the $U U J N$. While a notary is declared bankrupt based on a court 
decision that has permanent legal force, the sentence is dishonorably dismissed in accordance with Article 12 letter a of the UUJN.

The problem in the $U U J N$ is related to the bankruptcy of a notary, "the two articles above cause a blurring of norms because there is no further explanation because in the explanations of Article 9 paragraph (1) letter a and Article 12 letter a $U U J N$ stated quite clearly. In the absence of further explanation, it will lead to multiple interpretations regarding the bankruptcy of a notary, whether the status of the notary is as an individual (natuurlijk persoon) and the notary is a public official. Meanwhile, if you look at the provisions of the KPKPU Law, it has been clearly and more specifically explained regarding subjects that can be bankrupted, namely individuals and legal entities. [12]

By not stipulating bankruptcy in more detail regarding the bankruptcy of a notary as an individual or as a public official, it results in multiple interpretations. There should be an affirmation of intent in the provisions of Article 12 letter a of the UUJN whether as a person or an organ of his notary position. A notary who is declared bankrupt has the position as a legal subject, not in the name of the position, because what is declared a legal subject in bankruptcy is a subject who is a person and a legal entity, while the position of a notary is not a legal entity, the provisions in Article 12 letter a $U U J N$ apply personally and separately.

\section{Analysis and Discussion}

\subsection{Case of Position of Application for PKPU Case Number 20/Pdt.Sus-PKPU/PN.Niaga Sby}

Notary Devi Chrisnawati, acting as a person, filed an Application for Suspension of Obligation to Pay Debt $(P K P U)$ at the Surabaya Commercial Court. This is stated in the $P K P U$ case Number 20/Pdt.Sus-PKPU/PB.Niaga Sby. This PKPU application is due to the fact that she is no longer able to pay his debts to creditors that have matured due to the business she is undergoing which goes bankrupt. The purpose and objective of the PKPU Application submitted by the Petitioner through her attorney is to extend the time for the temporary suspension of debt payment obligations for 45 (forty-five) days and several matters relating to it to the Petitioner.

In the end, the Temporary PKPU Application was approved as a Permanent $P K P U$ for 45 days with the intention of giving debtor Devi Chrisnawati (in $P K P U$ ) time to prepare and submit a peace plan to her creditors. After the creditors' meeting with the agenda of matching receivables followed by verification of Devi Chrisnawati's debt (in PKPU) based on a list of temporary invoices as prepared by the management, Devi Chrisnawati did not attend. Likewise, in the creditor meeting there were protests submitted by concurrent creditors and their legal representatives, which in essence asked them to continue to try to present debtor Devi Chrisnawati directly (in $P K P U$ ), in an additional creditor meeting, the agenda of which was later agreed upon that the agenda meeting again provided an opportunity for legal counsel. presenting debtor Devi Chrisnawati, but she is still not present, so the Management Team reported to the Supervisory Judge providing its recommendation therefore the Panel of Judges in their decision declared the debtor bankrupt with all the legal consequences. In the end, the Surabaya Commercial Court judge granted the Petitioner's request and decided to declare the PKPU applicant Devi Chrisnawati bankrupt with all the legal consequences. 


\subsection{Legal Consequences Against Notary Declared Bankrupt Based on Court Decision Number 20/Pdt.Sus-PKPU/PN.Niaga Sby}

The inability to pay their debts to creditors in people's lives, especially for business people, often occurs and is experienced by debtors, both individuals and legal entities [13]. There are many factors that debtors stop paying debt installments to creditors which can cause them to be declared bankrupt, one of which is a company that managed to go bankrupt due to the economic crisis [11], or unable to compete in the market due to lack of innovation in marketed products so that consumers leave products that are less innovative, while consumer needs and tastes change quickly following the trends of the times. With weak competitiveness, it will have an impact on the acquisition of income, profits and the company's financial ability to be unhealthy which will also result in the company not being able to cover operational costs and pay all obligations that are the burden of the company, namely paying employee salaries, taxes, loan installments and loans. interest so that the company ended up in bankruptcy.

Bankruptcy can also happen to individuals as experienced by Devi Chrisnawati, who also has a profession as a notary. Based on the researcher's search through the Supreme Court's website which contains information on court decisions, this is the first and only time someone on behalf of a person who is also a notary has filed a $P K P U$ and the application was granted and declared bankrupt with all the legal consequences, namely in the case of Decision Number 20/Pdt.Sus-PKPU/2020/PN Niaga Sby. Based on her request, Devi Chrisnawati explained that her work as a private sector is not a notary profession, so that in her there are two legal subjects, namely as a person and a notary profession.

The problem in this case is that Devi Chrisnawati herself also works as a notary even though she filed a $P K P U$ on behalf of a person who was later declared bankrupt. Meanwhile, the Regional Supervisory Council $(M P W)$ has reported notary Devi Chrisnawati to be dishonorably discharged after the Surabaya Commercial Court judge decided to declare bankruptcy. This is based on the provisions of Article 12 letter a UUJN which expresses that: "A Notary is disreputably excused from his situation by the Minister at the idea of the Central Supervisory Council (MPP) whenever proclaimed bankrupt dependent on a court choice that has extremely durable legitimate power".

Since "Decision Number 20/Pdt.Sus-PKPU/2020/PN Niaga Sby was decided on July 10, 2020 and there has been no cassation to the Supreme Court, the decision is declared to have permanent legal force. In the case of bankruptcy, against the decision of the Commercial Court at the first level, and in particular concerning the petition for bankruptcy and the suspension of the obligation to pay debts based on Article 11 Paragraph (1) of the KPKPU Law, the legal remedy that can be filed against the decision on the petition for a declaration of bankruptcy is an appeal to the Supreme Court. Meanwhile, the creditors of PT. Bank OCBC NISP, Tbk has also announced the auction of bankrupt assets belonging to notary Devi Chrisnawati, namely several parcels of land and buildings organized by the Surabaya State Property and Auction Service Office $(K P K N L)$ which was held on January 11, 2021. [14]

Notaries as subjects of bankruptcy in the $U U J N$ have indeed been widely used as legal studies considering that there is a problem of unclear legal norms in Article 12 letter a of the $U U J N$. The ambiguity of norms in a law will lead to multiple interpretations and will result in its application causing legal uncertainty [9], and injustice for the bankrupt. Meanwhile, if you look at the norm provisions in Article 1 Paragraph (3) of the KPKPU Law, it states that what is meant by "debtors are people who have debts due to an agreement or law whose payment can be collected before the court". 
In relation to the bankruptcy notary, there are 2 (two) things that need to be underlined in the provisions of Article 1 Paragraph (3) of the KPKPU Law above, namely the sentences "person" and "debt". By referring to the sentence "person" then only the legal subject of the person can be bankrupted. While looking at the provisions in the KPKPU Law, there is no article that regulates certain positions or professions that can be bankrupted. Therefore, certain professions or positions such as a notary, for example, are not subject to bankruptcy, because the parties that can be declared bankrupt as regulated in the KPKPU Law are limited to only covering, namely:

1. Individuals or private entities, both married and unmarried men and women. If the application for a declaration of bankruptcy is filed by a married individual debtor, the application must obtain the approval of the husband or wife, unless there is a separation agreement.

2. Unions and other unincorporated associations. An application for insolvency against a firm should contain the name and spot of home of each firm which is mutually and severally destined for the whole obligation of the firm.

3. Organizations, affiliations, cooperatives and establishments that are legitimate substances. For this situation, the arrangements in regards to the power of each legitimate element as specified in the articles of affiliation will apply.

4. Heritage or legacy that has not been conveyed to the main beneficiaries as a different assortment of resources. [11]

Based on the provisions of Article 1 Paragraph (3) of the KPKPU Law, "that which can be used as a subject for bankruptcy is a personal person or a person not a person's position or profession as referred to in Article 12 letter a $U U J N$. While the object is the property it has. A notary who is declared bankrupt based on a court decision is basically a legal subject of a person (rechtspersoon), not as a certain profession or position, because what is meant as a legal subject here is a person and a legal entity, while the position of a notary attached to a person cannot be classified as a legal entity, but it only represents people's legal subjects. Therefore, the provisions in Article 12 letter a of the $U U J N$ can only be interpreted to apply to legal subjects of people."

The next legal problem that then arises in relation to the notary profession is the lack of a clear definition of "debt". In Article 1 Paragraph (6) of the KPKPU Law it is only explained: "Obligation is a commitment that is expressed or can be expressed in the measure of cash both in Indonesian money and unfamiliar money, either straightforwardly or that will emerge later on or unexpected, emerging from an understanding or law and which should be satisfied by the account holder and if not satisfied, gives the loan boss the option to get satisfaction from the borrower's resources."

This is certainly different from the definition regulated in the KPKPU Law with the meaning of debt which is often interpreted in the practice of commercial courts. The definition of debt can also be interpreted broadly which includes not giving up something or achievements that are obligations. The concept of this understanding when associated with the UUJN is considered quite appropriate, where a notary is given the authority to make authentic deeds and other matters but is not carried out properly or is in default which then results in losses and the aggrieved party prosecutes compensation and the court declares the notary concerned must pay the loss. If the compensation is not paid, it can be interpreted as a debt that can be collected.

That the issue of legal norms in Article 12 letter a of the $U U J N$ is considered to have quite serious implications, especially for someone who works as a notary who is also a businessman whose status is a debtor. If the debts meet the conditions for bankruptcy or because they personally apply for a postponement of debt payments, which then the judge of the commercial 
court grants and declares bankruptcy with all the legal consequences, the legal consequences that can be imposed on the notary can be dishonorably dismissed. The mechanism for dishonorable dismissal for bankrupt notaries is implemented after a commercial court decision has permanent legal force submitted by the Central Supervisory Council $(M P P)$ both manually and electronically.

As a result of being dishonorably dismissed due to bankruptcy, the legal consequences will be the loss of all rights under his authority and no obligation to carry out services in accordance with Article 15 of the $U U J N$. In the sense that the position of a notary attached to him has disappeared so that there is no longer the ability to carry out some of the activities of the state's duties, namely making authentic deeds, agreements and other legal actions.

Another legal consequence is if a notary is declared bankrupt and dishonorably dismissed, even though Article 215 to Article 221 of the KPKPU Law has regulated rehabilitation for parties declared bankrupt, but for the position of a notary who has been dismissed after the rehabilitation is granted, the court does not automatically bankrupt debtor which does not make a notary reappointed. Recovery is the reclamation of the great name of the borrower who was initially proclaimed bankrupt, through a court choice containing an explanation that the account holder has satisfied his commitments.

A fairly basic reason for a bankrupt debtor does not to make a notary public able to be reappointed because the provisions in the $U U J N$ do not regulate the re-appointment of a notary who has been dishonorably dismissed, except for a notary who is temporarily dismissed because in the bankruptcy process, then an application for reappointment can be submitted. For the reappointment mechanism for a notary who was temporarily dismissed due to being in the bankruptcy process or violating other criminal acts, there have not been found rules that specifically regulate it.

\subsection{Legal Position of Notary Who Has Bankrupt Status Based on Court Decision Number 20/Pdt.Sus-PKPU/PN.Niaga Sby}

Devi Chrisnawati's bankruptcy is an individual and the only person who is attached to her position as a notary. However, considering that Article 12 letter a of the UUJN does not provide further explanation regarding the bankruptcy of a notary, whether as a person or as a notary profession, Devi Chrisnawati's position as a notary is also affected. As previously explained, Notary Devi Chrisnawati has been reported to $M P W$ to be dismissed because she has been declared bankrupt by the Surabaya Commercial Court in the case of Decision 20/Pdt.SusPKPU/2020/PN Niaga Sby.

According to the author's view, "a notary as an official position is inappropriately subject to the provisions of the KPKPU Law, and therefore the provisions contained in the KPKPU Law cannot be applied in the case of Devi Chrisnawati to be dismissed from her position because in the KPKPU Law it has been emphasized that the subject of bankruptcy is a person not a position or certain professions including the profession as a notary. This is also what must be distinguished from the bankruptcy of a notary who is subject to Article 12 letter a of the UUJN because of her mistake in making an authentic deed which caused the deed to lose its evidentiary power so that the aggrieved party sued for compensation, and after the court's decision decided the notary was guilty it turned out to have to pay the loss. whose value is so large that it drains the entire property of the notary until it is insufficient to pay compensation, then the notary can be declared bankrupt."

As per Shanti Rachmadsyah's perspective in her paper in web-based law entitled lawful results assuming a public accountant is announced bankrupt, as per the arrangements of Article 
12 letter a concerning the KPKPU Law which in her clarification expresses that a chapter 11 choice changes an individual's lawful status to become awkward to make legitimate moves, control, and deal with their resources since the liquidation presentation choice is articulated. Thus, in relation to a notary who is declared bankrupt, her position becomes incompetent to take legal action to make an authentic deed, agreement, determination and other legal actions stated in an authentic deed as regulated in Article 15 of the UUJN. [15]

Disrespectful dismissal applies not only to notaries who are declared bankrupt, but can be imposed on notaries who are subject to criminal sanctions whose criminal penalties are 5 (five) years or more, then based on Article 13 of the $U U J N$ the punishment for their position as a notary is dishonorable discharge. Disrespectful dismissal for a notary who is declared bankrupt in the author's view, "does not reflect legal certainty and justice for the person whose position as a notary is declared bankrupt. Due to the fact that the provisions in the case of a bankruptcy notary regulated in Article 12 letter a of the UUJN are not clear and have multiple interpretations so that they are not appropriate to be used as a basis for dismissal. This is in line with the opinion of Jefferson, "the reflection of legal certainty can be achieved if there is no ambiguity in the law (laws must not be vague). [8] Hazy legitimate standards can prompt treachery. Such shamefulness can be seen from the lawful development of Article 12 Paragraph (1) letter a which express "a public accountant can be excused from his position in case he is announced bankrupt dependent on a court choice whose choice has super durable lawful power." Just in view of the indistinct standards, an individual who functions as a legal official and runs his/her business then, at that point, fails and presents a legitimate activity for the PKPU application and is proclaimed bankrupt with every one of the lawful outcomes, and afterward being disreputably released. It is truly not worth the battle during training which costs very costly and in the wake of proceeding with the public accountant program, he/she actually needs to go through a long and twisting cycle to get an expert degree as a legal official.

In $U U J N$ there is no prohibition against notaries being involved in businesses that are run outside of their work. As a person who is attached to a professional position as a notary, of course he can carry out legal actions with other parties which will give birth to rights and obligations and responsibilities for each party based on an agreement or engagement that has been mutually agreed upon or based on the law that governs it. In the sense that if the legal action is in the name of a person, then everything related to it has a relationship between personally with certain parties mentioned in the engagement only. Vice versa if the action is in the name of the profession as a notary, it will not only result in the notary and the parties or clients who need his services but also to the state through the authorized institution.

Seeing the instance of Devi Chrisnawati who recorded a PKPU application for her own sake and was announced bankrupt, then, at that point, when alluding to the arrangements of the KPKPU Law her status and position as a borrower who has obligations to lenders. "As indicated by Article 1 point 6 of the KPKPU Law, obligation is characterized as a commitment that is expressed or can be expressed in a measure of cash both in Indonesian money and unfamiliar cash, either straightforwardly or which will emerge later on or unexpected, emerging from an arrangement or law. the law and which should be satisfied by the indebted person and in case it isn't satisfied, it gives the leaser the option to get satisfaction from the debt holder's resources.

In this case, according to the author's view, the notary is not a debtor and cannot be bankrupted as described above because in the KPKPU Law only individuals and legal entities can be bankrupt. In the case of Devi Chrisnawati, the object of bankruptcy should be her wealth, not her profession as a notary. Indeed, in Devi Chrisnawati, apart from being a person, there is actually no separation of assets as a notary. Assets obtained from salary or honorarium as a notary and as a business actor or other business become an inseparable asset. Thus, even though 
in the provisions of the $K P K P U$ Law, a position or profession cannot be bankrupted, but if an individual has been declared bankrupt, his position as a notary will also be affected so that he is considered a bankrupt notary.

\section{Closing}

\subsection{Conclusion}

As a result of being dishonorably dismissed due to bankruptcy, the legal consequences will be the loss of all rights under his authority, namely making authentic deeds and other authorities and not having the obligation to carry out services in accordance with Article 15 of the UUJN. In the sense that the position of a notary attached to her has disappeared so that there is no longer the ability to carry out some of the activities of the state's duties, namely making authentic deeds, agreements and other legal actions. Another lawful outcome is if a legal official is proclaimed bankrupt and shamefully excused, despite the fact that Article 215 to Article 221 of the KPKPU Law hosts-controlled recovery for gatherings announced bankrupt, however for the situation of a public accountant who has been excused after the restoration is allowed, the court doesn't naturally that the bankrupt indebted person doesn't make a public accountant reappointed by the Ministry of Law and Human Rights. Recovery is the reclamation of the great name of the debt holder who was initially pronounced bankrupt, through a court choice containing an explanation that the indebted person has satisfied his/her commitments.

The legal position of a notary who is bankrupt based on a court decision in the case of Decision Number 20/Pdt.Sus-PKPU/2020/PN Niaga Sby, that by looking at the case of Devi Chrisnawati who filed a $P K P U$ application on her personal behalf and was declared bankrupt, then when referring to the provisions of the KPKPULaw on the status and position of the debtor. A person who in himself/herself serves as a notary is only the capacity of his/her position as a person who can be bankrupted with the object of bankruptcy of his/her assets, while his/her position as a notary profession is not a subject of bankruptcy, because only individuals and legal entities can be bankrupt.

\subsection{Suggestion}

Notaries who also run other businesses outside their positions, they should be able to anticipate and take into account the possibility that if one day their business goes bankrupt and then take legal steps for a PKPU application that the court decides to be declared bankrupt and dishonorably dismissed, then they will lose being notaries again. There is no mechanism for reappointment for a notary who has been dishonorably dismissed because of bankruptcy or for committing a criminal act with a sentence of 5 (five) years. The government and the legislature should review the provisions of Article 12 letter a concerning notaries who are dishonorably discharged for notaries who are declared bankrupt based on a court decision. These provisions are not clear and have multiple interpretations therefore they do not reflect legal certainty and justice for notaries who have other businesses if one day they experience bankruptcy, the position as notaries will also be affected.

\section{References}


[1] Harris, Freddy dan Leny Helena. Notaris di Indonesia. Cetakan Kedua. Lintas Cetak Djaja, Jakarta (2017).

[2] Nuswardani, Nunuk. Buku Ajar: Pengantar Hukum Administrasi. Surabaya: Scopindo Media Pustaka, (2019).

[3] Tobing, G.H.S. Lumban. Peraturan Jabatan Notaris. Cetakan ke-2. Erlangga, Jakarta (1982).

[4] Tim Redaksi Tatanusa. Jabatan Notaris: Perpaduan Naskah Undang-Undang Nomor 30 Tahun 2004 dengan Undang-Undang Nomor 2 Tahun 2014. Cetakan Pertama. Tata Nusa, Jakarta (2014).

[5] Adjie, Habib. "Rosidah Sudah Menjalankan Jabatan Sesuai UU Jabatan Notaris". Media Notaris, Edisi 25 Oktober 2017, in https://medianotaris.com/, accessed on February, 8 (2021).

[6] Nasrudin, Udin. "Menghindari Jerat Hukum, Notaris Harus Bagaimana?" in https://notariat.unpas.ac.id, Accessed on April, 14, 2021.

[7] Redaksi Jawapos, "Polrestabes Proses 7 Laporan Polisi Terkait Notaris Devi Chrisnawati." Derived from https://www.jawapos.com/surabaya/29/07/2020, accessed on 14 April 2021.

[8] Jefferson, Michael. Criminal Law. Pitman Publishing, London (1992).

[9] Manullang, E. Fernando M. Legisme, Legalitas dan Kepastian Hukum. Edisi Pertama. Cetakan kedua. Kencana, Jakarta (2017).

[10] Rasuanto, Bur. Keadilan Sosial Pandangan Deontologis Rawls dan Habermas Dua Teori Filsafat Politik Modern. Gramedia Pustaka Utama, Jakarta (2005).

[11] Widjaja, Gunawan. Resiko Hukum dan Bisnis Perusahaan Pailit. Cetakan ke-1. Forum sahabat, Jakarta (2009)

[12] Maylaksita, Amanda. "Problematik Interpretasi Pengaturan Kepailitan Terhadap Jabatan Notaris di Indonesia”, Lex Renaisance, No. 1 Vol. 4 Januari 2019.

[13] Asikin, Zainal. Hukum Kepailitan dan Penundaan Pembayaran Utang di Indonesia. Cetakan ke-1. Pustaka Reka Cipta, Bandung (2013).

[14] lelangdjkn.kemenkeu.go.id.

[15] Rachmadsyah, Shanti. "Akibat Hukum Jika Notaris Dinyatakan Pailit”. Derived from www.hukumonline.com, accessed on 22 Agustus 2021. 